\title{
The Alignment of Innovative Learning Environments and Inclusive Education: How Effective is the New Learning Environment in Meeting the Needs of Special Education Learners?
}

New Zealand Journal of Teachers' Work, Volume 13, Issue 2, 81-98, 2016

\section{ANGELA PAGE}

University of New England

\author{
ALEX DAVIS \\ Ormiston Senior College
}

\begin{abstract}
This article examines Innovative Learning Environments (ILE's) in terms of its promise to deliver an inclusive environment. While ILE's underpinning philosophy is to be inclusive for all, it appears that inclusion serves the needs of a wider mainstream audience. The article considers the research in this area critically, with a focus on the inclusive needs of students with disabilities and asks-whose inclusive needs are best served in an ILE context? This article argues that inclusion in an ILE which addresses the needs of students with disabilities has yet to be fully realised, and that an alternative inclusive education (IE) paradigm is required that aligns itself with the new ILE pedagogical environment.
\end{abstract}

\section{INTRODUCTION}

There has been much interest in the last few years resulting in a growing conversation about new ways of educational thinking. Within this new discourse, young people are described as life-long learners who are required to engage in an active process of knowledge acquisition across a range of contexts (Boersma, ten Dam, Wardekker, \& Volman, 2016; Schrittesser, Gerhartz-Reiter, \& Paseka, 2014). Yesterday's industrial economy provided an education that relied on reading and writing and other subjects that emphasised recall over understanding. The one-size-fits all approach does not lend itself to the needs of the new knowledge economy, which encourages the development of skills and values for a modern society (Griffin, McGaw, \& Care, 2012).

Thus, the traditional and persistently applied obsolete mode of the industrial model of education, and more importantly the thinking that underpins it, is viewed as redundant in current pedagogical practice (Bolstad et al., 2012). The shift to a new paradigm is driven by a consciousness of significant social, economic and technological change, and the exponentially increasing amount of human knowledge being generated as a result (Gilbert, 2005). International 
thinking has begun to seriously examine questions about the role and purpose of education in a world that has an unprecedented degree of complexity, fluidity and uncertainty (Beetham \& Sharpe, 2013; Kuhlthau, Maniotes, \& Caspari, 2015).

Alongside these economic, social, political and technological changes, many serious challenges characterise the 21st century world, cutting across all societal domains. Therefore, the "need to rethink our ideas about how our learning systems are organised, resourced and supported" (Bolstad et al., 2012, p. 2) becomes paramount in a rebundle of learning and teaching to better reflect the demands of the new world.

This rethinking also applies to the prevalent design of school buildings. Locke and Sheerin (2010) describe that the current building stock of schools in New Zealand was built for the transmission style of teaching and learning of the 1950s and 1960s, and requires revisiting. These classrooms are designed in linear blocks for students sitting in desks in rows, and lack any flexibility from a teaching and learning perspective. The challenge therefore, is to now align the educational needs that correspond with $21^{\text {st }}$ century learning in a way that does not "divorce the classroom of the future from thinking about the school of the future" (slide 7).

In our roles of researchers, inclusive educators and project managers, we have been involved in the implementation of educational redesign. We wish to raise in this article the important issues that still need to be addressed in order to align the new learning context for all students rather than for most students. The new learning environments in the $21^{\text {st }}$ century have been built around models using an ILE framework, which are designed to maximise inclusivity and active learning. However, while the ILE paradigm is considered to address many of the shortcomings of traditional models of inclusion, and is well supported in the literature (Blackmore et al., 2011; OECD, 2015) some groups of students, such as those with disabilities benefit by osmosis. In short, ILEs claim a robust and supportive space for inclusivity, but on the ground, it misses the mark for students with disability. This article will outline the support ILEs provide for IE, the benefits to students with disabilities, where ILEs do not address the delivery of IE for students with disability, and give examples of ILE schools that address special education as their primary goal. By presenting this information, a possible better way forward for students with disabilities in ILEs will be illustrated.

\section{INCLUSIVE EDUCATION}

Inclusive education is supported from the theoretical framework that recognises the rights of people with disabilities to have equal access and opportunity and was recognised in legislation with the passing of the Salamanca Statement calling for governments to give priority to inclusive education (UNESCO, 1994) and subsequently to ensure an inclusive education system at all levels (United Nations, 2006).

Current inclusive pedagogy extends what is ordinarily made available to others in their normal school day. In this way, teaching students with inclusive needs is a way of responding to differences between learners rather than specifically individualising for some. It represents a shift in thinking about 
teaching and learning from that which works for the average learner. Inclusive pedagogy has changed its focus from the delivery of different or additional material for students who fall outside typical student's needs, to an approach to teaching and learning that involves learning opportunities that are sufficiently made available to everyone (Liasidou, 2014). In other words, it is an approach that responds to individual differences and avoids marginalising students, which can occur when learners are treated differently (Spratt \& Florian, 2015). While this is an admirable aim however, the practice in many schools has fallen short of the policies put into place (Mittler, 2012).

\section{Special education policy in practice}

It is generally accepted in mainstream schools to advocate for the inclusion of disabled students with special educational needs in regular classrooms, however advocacy does not always lead to implementation (Florian, 2014; Vaz et al., 2015). Forbes (2007) for example, discusses a policy/practice divide that is perpetuated and shows that there are few references to processes that have been implemented in order for inclusion to be successful.

An additional barrier to the successful implementation of inclusion is the lack of teacher education in this area (Forlin \& Chambers, 2011). General education teachers have expressed concerns about their ability to implement inclusive practices and Hsien, Brown, and Bortoli (2009) state that teachers have reported low levels of confidence in regard to planning and implementing necessary modifications. Teacher education is believed to play a significant role in preparing teachers to implement inclusive practices (Florian, 2014). However, Forlin and Chambers (2011) report that even experienced teachers have concerns about their ability to cater for a diverse student body.

In reality, little is known about what works best to prepare teachers for the challenges present in today's classrooms (Florian, 2014); Walton, Nel, Muller, and Lebeloane (2014) found that many teachers struggle with the knowledge and skills that are needed to teach in classrooms with diverse learners and learning needs. Teachers are required to understand the disabilities and capabilities of the student, their potential and the levels of assistance required. Most of this is unknown to teachers prior to having a student with additional needs placed in their classroom. Not surprisingly then, Greenway, McCollow, Hudson, Peck, and Davis (2013) have identified that knowledge of different disabilities enhances teachers' understanding of the learning needs of the students they work with. Teacher education then, under the current IE paradigm appears to present itself with shortcomings in terms of its promise.

\section{Classroom teaching practices and delivery}

In regard to its delivery, teachers have been required to make many pedagogical shifts in recent years in terms of IE for students with a diversity of needs who are now enrolling in mainstream classes. Whereas IE for students with diverse needs has required a shift in the way traditional teaching occurs, including students with disabilities often requires additional teacher support. While support from teacher's aides is believed by many to be the best resource, assistance from other staff is also necessary. This includes support from colleagues, principals and specialist staff (Hemmings \& Woodcock, 2011; Shin, 
Lee, \& McKenna, 2016). Current practices of collaboration were investigated by Solis, Vaughn, Swanson, and Mcculley (2012). They synthesised collaborative models of instruction and found that the most typical model for implementing special education was one in which the general education teacher provided instruction and the special education teacher, who was typically employed in a subordinate role, provided support to students and teachers. It was recognised however, that fewer than $15 \%$ of the 146 studies included in the syntheses provided data on student outcomes, suggesting that the most promising interpretation of the data is that co-teaching is likely to be associated with small gains only.

Findings from these syntheses also suggest that when specialists recommended improved instructional practices to teachers, changes are unlikely to be realised in the classroom. Alternatively, when specialists coordinated curriculum changes, significant changes were more likely to occur. This finding offers support for the notion that to adequately address the needs of students with disability, IE need to take into account an individual's specific requirements and not allow special educational needs to be absorbed within a larger subset (Pearce, 2009; Selvaraj, 2015). Such findings and conclusions again support the rethinking of the current paradigm in terms of the delivery of IE.

\section{Rethinking practices for students with disabilities in education}

Teacher IE has fallen under criticism for some time not only in terms of the quality and quantity of training practices for pre-service teachers (Hemmings \& Woodcock, 2011; Shin et al., 2016), but also subsequent professional development. Waitoller and Artiles (2013) found that professional development research for IE has produced a "somewhat limited and fragmented knowledge base due to various forms of conceptualizing IE and teacher learning" (p. 347), claiming that teacher education for IE is under-theorised. This statement illustrates the difficulties of putting into practice a concept that is contestable and open to interpretation. Selvaraj (2015) discusses the struggle of applying IE policy in New Zealand where its implementation is fraught with the tension of realising its objectives because of such issues. Selvaraj suggests further that providing the tools with which each school can actively evaluate their own IE development may be a useful approach to achieve IE goals.

The discussion around IE needs to be wider however, as in this postindustrial era, it is now a worthwhile time to reconsider how and where special education sits within the broader context of education, especially in a period when we are poised on the edge of other significant changes. Banathy (2013) puts this succinctly:

There is an increased realisation of the massive social changes and transformations that are reflected in the new realities of the post-industrial information/knowledge era. The changes touch the lives of every person, family, community, and nation and define the future of humanity. However, we are entering the twenty-first century with organizations designed in the nineteenth. Improvement or restructuring of existing systems, based on the design of the industrial machine age, does not work anymore. Only 
a radical and fundamental change of perspectives and purposes, and the redesign of our organizations and social systems, will satisfy the new realities and requirements of our era. (p. 1)

As Banathy suggests, change in one area impacts on others. The impending transformations for IE as we move into a new era for $21^{\text {st }}$ century learning can therefore be an accidental addition or purposeful consideration.

\section{THE FIT BETWEEN ILE'S AND IE}

Attempts to meet these 'massive social changes' as Banathy described, requires teaching to be a creative process that is "about developing young people who are adaptable, collaborative, responsive, self-directed and capable of being self-managing in networks and far less hierarchical settings and communities than their parents experienced" (Atkin, 2010, p. 15). To achieve this end, a comprehensive study was conducted in 2010 by the Organisation for Economic Cooperation's (OECD) Centre for Educational Research and Innovation (CERI) and named the Innovative Learning Environments (ILE) Project (2013).

This article draws on the data from the ILE Project as this international study collected information from 25 contributing countries and provided evidence regarding outcomes and evaluations of ILEs (Istance, 2011). With a key focus that addressed access and equity, the OECD promised to lead the world out of what the OECD Secretary-General called a fiscal and social crisis (Gurria, 2009). Thus, the ILE Project embraced the theoretical underpinnings of inclusive education that promoted equal educational access and opportunity.

Additionally, the project analysed both the teaching and environmental conditions that lent themselves to better learning outcomes. A key aim of the project was to inform practice, leadership and reform by reporting on innovative and inspiring configurations of learning for students. The study characterised an ILE as:

- Learner-centered: focus of all activities,

- Structured and well designed: role of teachers in supporting inquiry and autonomous learning,

- Profoundly personalized: sensitive to individual and group differences in terms of background, prior knowledge, motivation and abilities,

- Inclusive: sensitive to individual and group differences in terms of learning needs,

- Social: learning most effective when cooperative and in-group settings (Blackmore et al., 2011, p. 18).

Each of these characteristics of an ILE lends itself to successful implementation of an IE environment. IE is most effective in a context that makes each student the centre of their learning and encourages autonomy, is 
sensitive to individual learning and backgrounds, and facilitates socialisation (Harris, Spina, Ehrich, \& Smeed, 2013; Thomas, 2013).

While the OECD study is nearing its final stages, it acknowledges that the effectiveness of ILEs are yet to be realised regarding any evidence-based support for learning outcomes (OECD, 2015). The positive perceptions of teachers and students in terms of its worth are, however, significant (Boersma et al., 2016). It is likely that positive student outcomes for all students may soon be realised, as the ILE approach encompasses many of Hattie's (2009) top rankings related to student achievement:

- micro teaching,

- teaching clarity,

- teacher-student relationships,

- spaced versus mass practice,

- meta-cognitive strategies,

- creative programmes,

- professional development, and

- problem-solving teaching.

\section{The role of space in ILEs}

In order to begin to apply the new pedagogical principles of ILEs, Atkin (2010) points to an intersection that exists between space and learning and reiterates that first, the need to develop classrooms that represent the beliefs and rationales of different theories and practice must be addressed. This is a sentiment echoed by Bernard (2012) who cites a model refined by Pigozzi (2006) that demonstrates the relationship between allowing for more flexible space that creates high levels and even different arrangements of student interaction.

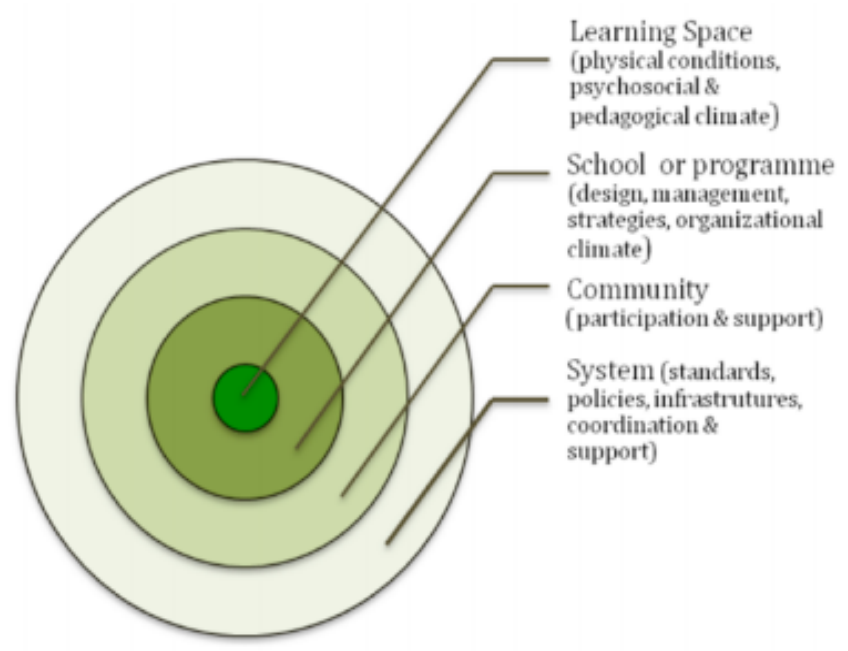

Fig. 1: Areas of impact on the quality of learning environments by level

Figure 1 shows the classroom space is at the centre of all learning activity. The quality of the classroom environment is embedded in the physical climate of the school, thus allowing the school to be part of the wider system. 
There are varying levels of control over the physical, organisational and pedagogical environment. These in turn, are also at the local level by community involvement and support as well as the broader social and cultural context.

The New Zealand Ministry of Education (2013, para. 7) explored the nature of the local context of those interactions, commenting on the connectedness and flexibility of space that they believe marks out an ILE not only in regards to sharing of space with the larger community but also how best to manipulate what can be shared within that space:

Specialist equipment within a school can be shared by all, and with the wider community. This could be a fully-fitted industrial kitchen, or a modern science laboratory lined with wall-to-wall glass that allows other students to walk past and observe what's going on. Whole walls can be whiteboard, or white-boards can be movable. Teachers can opt to change the way the class is facing, or break children up into groups. Today everything about a school can be designed with the needs of students in mind.

If space therefore, can have a critical impact on the ecology of the learning environment, then it is important to consider the implications for those who will benefit the most from it. Students with physical and sensory disabilities for example, have different needs for space (Davidson, 2015) and these requirements must be embedded in ILE design.

\section{The effect of space on staff and students}

The redesign of the learning environment represented by Bernard's presentation of Pigozzi's model of a new learning space, depict a greater focus on teaching and learning from a more ecological perspective. Instead of perceiving the "classroom is a container" (Leander, Phillips, \& Taylor, 2010, p. 329), new approaches to classroom design, according to the New Zealand Ministry of Education, enable teachers in ILE schools the opportunity to use greater innovative teaching practices that are adaptive in meeting the needs of students (Ministry of Education, 2013).

Innovative teaching practices are not the only change that ILE schools present. Mulcahy, Cleveland, and Aberton (2015) note that within ILE classrooms, the changing nature of the space also creates change in the social relationships between teachers as they seek to effect a new way forward and a new pedagogy. This in turn also affects the social relationships between students. One reason that accounts for this shift is discussed by Bradbeer (2015) who purports that because teachers have to work far more collaboratively together, given the proximity of the teaching team with one another, relationships are bound to change. This includes relationships between teachers, and also between teachers and every student in the ILE learning space, and between students themselves.

\section{ILE, IE and the learning environment}

Building on the model put forward by Bernard, Morrison (Morrison, 2015, p. 54) suggests that a new learning environment emerges as a result of the 
transformative processes that are taking place within the ILE framework, depicted in Figure 2.

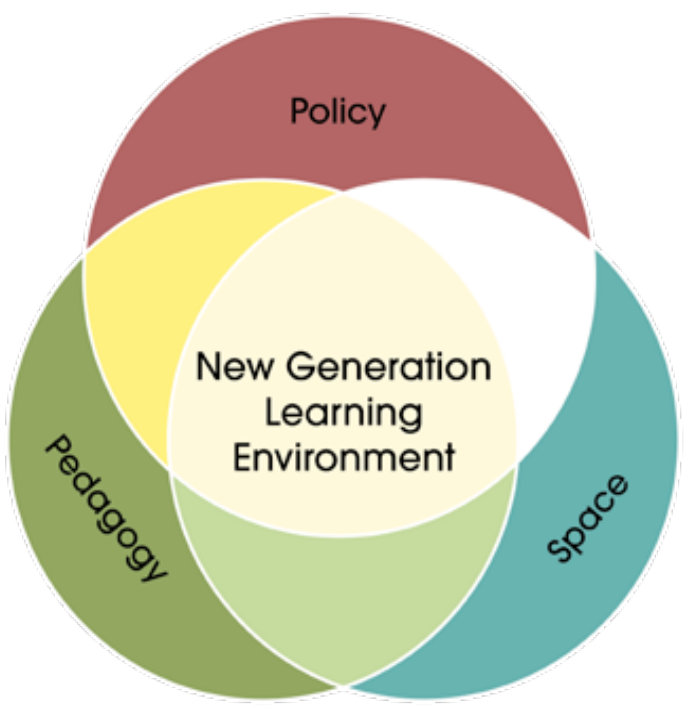

Fig. 2. Intraconnecting entities of policy-pedagogy-space

Here, Morrison shows the interaction between policy, pedagogy and space that creates new meaning for the actors. What occurs within this space transpires because it is organic and creative and therefore takes on unexpected twists and turns.

Experimenting in education is messy, unpredictable work. It is uncertain, nonlinear and undetermined. But it allows teachers and students to trial and enact different material and pedagogical practices. Perhaps more importantly, it places the everyday practices of teachers and students at the centre of pedagogical and spatial change. Learning environments are more learner-centred, relationships between teachers and students are changing, students have choices. (p. 58)

A new way of being, or behaving in the new learning environment is encouraged in the intersection of pedagogy, policy and space and engagement at this juncture creates an opportunity for systemic improvement not only for schools and teachers but for all students. Morrison's (2015) model presents inclusive educators with an exciting prospect: if the intersection between policy, space and pedagogy means a co-construction of a way forward for learning then perhaps the current pedagogy of inclusion needs to incorporate itself accordingly. At the moment, inclusive pedagogy sits alongside, but is fundamentally different from, mainstream education (Fulcher, 2015).

\section{ILE and benefits for students with disabilities}

While there are certainly benefits documented for students in the literature of ILEs that embrace the inclusion of all students, little reference is made to students with special needs or disability specifically. However, one of the more obvious benefits of ILEs is that the buildings themselves are 
accessible for students with physical disabilities. Modern open planned buildings also allow for the space of smooth student transitions from one segment of learning to the other, which is vital for students with disabilities and non-disabilities alike (Byers, 2015). Socialisation and collaboration is enhanced for students with disabilities through group work. Technology is employed to overcome specific disability access, learning, communication, independence, mobility, and social goals (Edyburn \& Howery, 2014). Another reported advantage for students with disabilities in an ILE is that the special education teacher is able to circulate between classes providing within this model, what is considered to be better support. Also, classes themselves are multi-level thus providing more meaningful engagement for those with a learning difficulty (OECD, 2013).

\section{Where ILE's fall short in the delivery of special education}

One of the challenges that face schools when considering the concept of an ILE, argues Hattie (2015), is the problem that "changing the shape of buildings does not lead to teachers teaching differently" (p. 17). Additional coaching is required for teachers to understand not only how to work together in this new environment, but also how to evaluate their impact when they are working in different spaces. As described earlier, teachers need specific special needs education and which Solis et al. (2012) proposed, should be developed across curriculum areas and not taught in a special education silo.

Another problematic issue for special education outcomes is that ILEs promote inquiry learning and self-regulation in its learners requiring high levels of self-regulation in innovative learning environments (Hornstra, van der Veen, Peetsma, \& Volman, 2014). Students with disabilities may need to be taught the skills necessary to engage in activities for any length of time. Self-regulation is even more challenging for students with cognitive disorders such as learning difficulties, emotional and behaviour disorders, intellectual disability, Attention Deficit, Hyperactivity Disorder, and Autism (Schunk \& Bursuck, 2012). Low achievers, as a subset of students with a disability, have also been reported to have difficulty with focus and self-control (Hattie \& Yates, 2014). A further concern is that students on the Autistic Spectrum may be required to participate with others in learning groups. Working in groups can be a real challenge for these students, as Autistic Spectrum Disorders are characterised as a social disability. Students on the Autistic Spectrum often have difficulty in understanding and coping with social situations and this difficulty can result in levels of high anxiety and challenging behaviours (White, Scahill, \& Ollendick, 2016). Additionally, students on the Autism Spectrum experience greater sensory processing problems than the rest of the population that can often affect social interactions where sensory overload results from factors that include noise and lighting (Robertson \& Simmons, 2013).

Robinson and Munro (2014) have noted concerns regarding hearing and sensory overload for students with disabilities in ILEs, and to investigate this problem, Mealings, Demuth, Buchholz, and Dillon (2015) conducted a study measuring the noise levels in open planned classrooms. The results revealed that open plan classrooms might not be appropriate learning environments for teaching young children due to their high intrusive noise levels, which negatively impact speech perception. Research conducted at the secondary school level showed that pupils who reported additional learning needs such as 
hearing impairment, speaking English as a second language or receiving learning support reported being significantly more affected by poor school acoustics than pupils reporting no additional learning needs (Connolly, Dockrell, Shield, Conetta, \& Cox, 2015).

Davidson (2015) reported on the use of physical space of twelve special schools across three countries who had implemented ILE classroom and pedagogical design and found that these bespoke schools offered good outcomes from opening the space. Davidson showed that open areas allowed better traffic flow, were well-lit and inviting, and offered quiet spaces for times of sensory overload. However open classrooms were also reported by staff to be distracting for students. Further, round tables were not useful to accommodate wheelchairs, and sometimes the students with Autistic Spectrum disorders could not cope well with the ever-changing organisation of furniture. While an analysis of special schools is a contradiction to the philosophy of ILE in terms of inclusion, it does offer some unique perspectives in terms of the practicalities of implementing the ILE framework for students with special needs. Of interest, the report noted that although the schools had transformed its learning spaces, the reasons for change were "seldom expressed within a pedagogical vision" ( $p$. 24 ), and so, little had changed in the way of teaching and learning.

One argument that can be put forward to explain or even excuse why ILEs fall short of delivering on their inclusion promise, is that IE looks different across contexts (Florian, 2014; Selvaraj, 2015). Because IE is open to interpretation, it is important that a common discourse is established between practitioners in ILEs that embrace all of the aspirations for IE. Given that new learning environments are co-constructed for all learners in each ILE, so then should students with disabilities be entitled to a specialist environment that is not an add-on, but developed within the same space.

The Inclusive Pedagogical Approach in Action Framework proposed by Florian (2014, p. 290) could enable the positioning of IE within an ILE. The framework encourages teachers to continually create new ways of working with others that challenge current thinking of inclusion from working with 'most' and 'some' to working with all students, adults, and community of the classroom. This in turn would lead to new models of working with students.

\section{REPOSITIONING IE WITHIN AN ILE FRAMEWORK}

\section{Schools that support a new framework and strategy}

Two exceptional schools have reported pioneering IE strategies that address the needs of students with disabilities in innovative ways. These case studies were part of sample from 125 schools formed from the OECD ILE project (OECD, 2013). Within the 125 case study ILEs, there are other examples that report IE as an important component of their education delivery, however often there is no further reference to the strategies that are put into place to address the needs of students with disabilities. Therefore, one is left to assume that IE is employed along the same lines as the policies of old in ILEs across the OECD.

The Keskuskouli School in Finland (Lieka Education Department, n.d.) is an example where the inclusion of special school students into an ILE setting in August 2009 for students with disabilities is discussed in detail. The Finnish 
example however, considers innovation to be the provision of a space where students with special needs are included in class with a special education teacher and have teacher aides delivering a specialist programme to these individuals during regular lessons. While Keskuskouli School can be considered pioneering in terms of its own changing context from a special school delivery to a more inclusive delivery of education for its students with disabilities enabled by the ILE space, it remains the same in terms of approaching teaching for students with disabilities according to IE traditional pedagogy.

Another case study school included in the OECD project is the Jenaplan School in Germany. It uses a holistic approach to provide inclusion for all students and highlights the needs of students with disabilities. The school views every child at the centre of learning and social interactions are highly valued. Students with lower ability receive support from older peers and classes are mixed in age, which addresses academic differences within its levels. Individualised support is provided where required for students with special needs. It was found that the mixed-age groups needed greater individualised treatment of the learning content and so for example, two different ways of teaching mathematics in the middle group are used, or alternatively, individual or paired learning is offered (Gläser-Zikuda, Ziegelbauer, Rohde, Conrad, \& Limprecht, 2012). Jenaplan School offers a distinctly different approach to teaching that facilitates every child's individual learning needs while at the same time emphasising group membership.

The most exciting pedagogical innovation of the IE space reported is by a pre-primary and primary state school in Spain. The Analucia School caters for special educational needs due to disadvantaged social conditions, where all learners are at risk of exclusion and very high numbers are identified as belonging to the Gypsy community (Bernabeu Moron, Turrado López, \& Fernández de los Ríos, 2012). Given this context, the school has prioritised special educational needs within their ILE. It was identified that the teachers lacked training in special education, particularly due to the school's sociocultural disadvantage, and so specialised training was given to all staff when a new ILE was implemented. Not only did this occur during school time for staff, but students participated in IE training as well. The result of every member of the ILE participating in IE training is that everyone can communicate and participate with students with disabilities. A good example that was given to illustrate this was that sign language was taught to students and staff during class time, enabling all members of the school to communicate with the student who was hearing impaired. This is an excellent application of Florian's model of inclusion from working with 'most' and 'some' to working with all students and adults in the classroom (2014).

The Analucia School report to the OECD specifically addresses educational inclusiveness and special educational needs and it does so by adopting methods that are truly innovative in its practice of IE for students with disabilities. It is important to note that while these changes occurred within the context of an ILE, all educational environments can benefit from an approach that ensures that "no pupil is excluded" (Bernabeu Moron et al., 2012, p. 28) in its truest sense. 


\section{DISCUSSION}

This article examined ILEs in terms of the promise to deliver an inclusive environment for all. It also examined schools within the OECD ILE Project and looked for examples of implementing IE within the ILE framework. While the number of participating countries in the project was high (25) there was a noticeable lack of reporting from the schools that discussed strategies to address not only IE, but education for special needs and/or disability. Consider the OECD premise stated by Gurria (2009) for learning in the 21st century that relocates education as the development of knowledge for economic advantage in order to address the fiscal crisis. This positioning of education may explain the absence of students with disabilities within OECD research and we are left to wonder what role, if any, the economics of disability has in the classroom.

This article also sought to argue that inclusion in an ILE which addresses the needs of students with disabilities has yet to be fully realised or achieved, and that an alternative IE paradigm is required that sits alongside the new ILE pedagogical framework. This paper has raised some provocative discussion from various authors in regard to possible future frameworks for IE, and new IE implementation using ILEs as a mechanism for change. ILEs advocate for inclusivity, which is sensitive to individual and group learning needs. While inclusion in an ILE that addresses the needs of students with disabilities requires more time to reach its potential, an alternative IE paradigm that aligns itself with the new ILE pedagogical environment seems more desirable. A new paradigm would benefit from embracing the new meaning that is afforded to learners in Morrison's (2015) ILE model; where the coconstruction for learners also takes into account learners with special needs. Florian's (2014) framework may enable this goal to be realised-to embed IE within an ILE where all teachers work with all students in a re-construction of new relationships between staff and students. Florian's suggestion to engage in active learning is already an integral component in ILEs but its significance has been missed in its application for students with disabilities. The model recognises the need for a wider lens that allows the value of the relationship between the teacher and the student that takes the child and their contributions seriously to be fully appreciated.

\section{CONCLUSION}

The purpose of this article was to provoke a conversation around a new pedagogy for learners with disabilities that allows these students to become full participatory members in their ILE. ILEs are located in a time and place that allows and encourages change and the creation of new ideas. IE advocates and researchers must seize this moment and ensure that policies and practices are appropriately positioned for students with special needs.

\section{Manuscript Submitted: April 28, 2016}

Revised Manuscript Received: August 11, 2016

Revised Manuscript Accepted: August 31, 2016 


\section{REFERENCES}

Atkin, J. (2010). What make a learning environment innovative? Retrieved from Department of Education and Early Childhood Development: http://www.education.vic.gov.au/edulibrary/public/teachlearn/innovation/l pd/ile/expo1/atkin.pdf

Banathy, B. H. (2013). Designing social systems in a changing world. New York, NY: Springer Science \& Business Media.

Beetham, H., \& Sharpe, R. (2013). Rethinking pedagogy for a digital age: Designing for 21st century learning. New York, NY: Routledge.

Bernabeu Moron, N., Turrado López, A., \& Fernández de los Ríos, J. A. (2012). Innovative learning environments (ILE), Inventory case study: Andalucía (Seville, Spain). Spain: Directorate for Education, Centre for Educational Research and Innovation (CERI), OECD. Retrieved from https://www.oecd.org/edu/ceri/49930737.pdf

Bernard, J. (2012). A place to learn: Lessons from research on learning environments. UNESCO Institute for Statistics, Montreal, Canada. Retrieved from http://unesdoc.unesco.org/images/0021/002154/215468e.pdf

Blackmore, J., Bateman, D., Cloonan, A., Dixon, M., Loughlin, J., O’Mara, J., \& Senior, K. (2012). Innovative learning environments research study. Melbourne: Department of Education and Early Childhood, Victoria/OECD. Retrieved from http://www.learningspaces.edu.au/docs/learningspaces-final-report.pdf

Boersma, A., ten Dam, G., Wardekker, W., \& Volman, M. (2016). Designing innovative learning environments to foster communities of learners for students in initial vocational education. Learning Environments Research, 19(1), 107-131. doi: 10.1007/s10984-015-9203-4

Bolstad, R., Gilbert, J., McDowall, S., Bull, A., Boyd, S., \& Hipkins, R. (2012). Supporting future-oriented learning \& teaching: A New Zealand perspective. Ministry of Education Wellington. Retrieved from https://www.educationcounts.govt.nz/publications/schooling/109306

Bradbeer, C. (2015, June). 'Finished beginnings': Finding space for time in collaborative teacher practice. Paper presented at the Terrains 2015 Mapping learning environment evaluation across the design and education landscape: Towards the evidence-based design of educational facilities, Melbourne: Australia. Retrieved from http://e21le.com/wpcontent/uploads/2015/11/Terrains2015WebSmall.pdf

Byers, T. (2015, June). The empirical evaluation of the transition from traditional to New Generation Learning Spaces on teaching and learning. Paper presented at the Terrains 2015 Mapping learning environment evaluation across the design and education landscape: Towards the evidencebased design of educational facilities, Melbourne: Australia. Retrieved from http://e21le.com/wpcontent/uploads/2015/11/Terrains2015WebSmall.pdf 
Connolly, D. M., Dockrell, J. E., Shield, B. M., Conetta, R., \& Cox, T. J. (2015). Students' perceptions of school acoustics and the impact of noise on teaching and learning in secondary schools: Findings of a questionnaire survey. Energy Procedia, 78, 3114-3119. doi:10.1016/j.egypro.2015.11.766

Davidson, K. (2015). Sabbatical report. Retrieved September 20, 2016, from http://www.educationalleaders.govt.nz/Leadershipdevelopment/Professional-information/Principals-sabbaticalreports/Primary-award-recipients-2015

Edyburn, D. L., \& Howery, K. (2014). How is technology used to support instruction in inclusive schools? In J. McLeskey, N. L. Waldron, F. Spooner, \& B. Algozzine (Eds.), Handbook of effective inclusive schools: Research and practice (pp. 167-180). New York, NY: Routledge.

Florian, L. (2014). What counts as evidence of inclusive education? European Journal of Special Needs Education, 29(3), 286-294. doi: 10.1080/08856257.2014.933551

Forbes, F. (2007). Towards inclusion: An Australian perspective. Support for Learning, 22(2), 66-71. doi: 10.1111/j.1467-9604.2007.00449.x

Forlin, C., \& Chambers, D. J. (2011). Teacher preparation for inclusive education: Increasing knowledge but raising concerns. Asia-Pacific Journal of Teacher Education, 39,(1), 17-32. doi: 10.1080/1359866X.2010.540850

Fulcher, G. (2015). Disabling policies?: A comparative approach to education policy and disability. New York, NY: Routledge.

Gilbert, J. (2005). Catching the knowledge wave? The knowledge society and the future of education. Wellington, New Zealand: NZCER Press.

Gläser-Zikuda, M., Ziegelbauer, S., Rohde, J., Conrad, M., \& Limprecht, S. (2012). Innovative Learning Environments (ILE) Inventory Case Study The Jenaplan School of Jena Germany (Thuringia). Germany: Directorate for Education, Centre for Educational Research and Innovation (CERI), OECD. Retrieved from https://www.oecd.org/edu/ceri/DEU.THU.003.\%20Finalwihcover.pdf

Greenway, R., McCollow, M., Hudson, R. F., Peck, C., \& Davis, C. A. (2013). Autonomy and accountability: Teacher perspectives on evidence-based practice and decision-making for students with intellectual and developmental disabilities. Education and Training in Autism and Developmental Disabilities, 48(4), 456-468.

Griffin, P., McGaw, B., \& Care, E. (2012). The changing role of education and schools. In P. Griffin, B. McGaw, \& E. Care (Eds.), Assessment and teaching of 21st century skills (pp. 1-16). Melbourne, Australia: Springer.

Gurria, A. (2009, 5 July). The new dynamics of higher education and research for societal change and development. Paper presented at the UNESCO World Conference on Higher Education, Paris. Retrieved from http://www.oecd.org/edu/thenewdynamicsofhighereducationandresearchf orsocietalchangeanddevelopment.htm

Harris, J., Spina, N., Ehrich, L. C. \& Smeed, J. (2013). Literature review: Student-centered schools make the difference. Retrieved from http://www.aitsl.edu.au/docs/default-source/eCollection/literature-reviewstudent-centred-schools-makethe-difference.pdf 
Hattie, J. (2009). Visible learning: A synthesis of over 800 meta-analyses related to student achievement. London, England: Routledge.

Hattie, J. (2015). What works best in education: The politics of collaborative expertise. London, England: Pearson.

Hattie, J. A. C., \& Yates, G. C. R. (2014). Using feedback to promote learning. In V. A. Benassi, C. E. Overson, \& C. M. Hakala. Applying science of learning in education: Infusing psychological science into the curriculum (pp. 45-58). Divison 2, American Psychological Association.

Hemmings, B., \& Woodcock, S. (2011). Preservice teachers' views of inclusive education: a content analysis. Australasian Journal of Special Education, 35(2), 103-116. doi: https://doi.org/10.1375/ajse.35.2.103

Hornstra, L., van der Veen, I., Peetsma, T., \& Volman, M. (2014). Innovative learning and developments in motivation and achievement in upper primary school. Educational Psychology, 35(5), 598-633. doi:10.1080/01443410.2014.922164

Hsien, M., Brown, P. M., \& Bortoli, A. (2009). Teacher qualifications and attitudes toward inclusion. Australasian Journal of Special Education, 33(1), 26-41. doi: https://doi.org/10.1375/ajse.33.1.26

Istance, D. (2011). Innovative learning environments: An international perspective. Melbourne, Australia: Centre for Strategic Education. Retrieved from http://www.innovations.sa.edu.au/files/links/Seminar_Paper_210_2.pdf

Kuhlthau, C. C., Maniotes, L. K., \& Caspari, A. K. (2015). Guided inquiry: Learning in the 21st century. Santa Barbara, CA: ABC-CLIO.

Leander, K., Phillips, N., \& Taylor, K. (2010). The changing social spaces of learning: Mapping new mobilities. Review of Research in Education, 34, 329-394. doi: 10.3102/0091732X09358129

Liasidou, A. (2014). Inclusive education and critical pedagogy at the intersections of disability, race, gender and class. Journal for Critical Education Policy Studies, 10, 168-184.

Lieka Education Department. (n.d.). Finland. From Special Education Classes Towards Inclusion in Expanding Learning Environments. OECD Innovative Learning Environment Project. Retrieved from http://www.oecd.org/edu/ceri/49750440.pdf

Locke, J., \& Sheerin, B. (2010). Spaces for learning. [PowerPoint slides]. Retrieved from http://www.educationalleaders.govt.nz/content/download/6222/50131/file/

Mealings, K. T., Demuth, K., Buchholz, J., \& Dillon, H. (2015). The Development of the Mealings, Demuth, Dillon, and Buchholz Classroom Speech

Perception Test. Journal of Speech, Language, and Hearing Research, 58(4), 1350-1362. doi: 10.1044/2015_JSLHR-H-14-0332

Ministry of Education. (2013). Modern learning environments [Fact sheet]. Retrieved from http://shapingeducation.govt.nz/wp-content/uploads/2013/05/MOE-FactSheet-7 Modern-Learning-Environments-WEB.pdf

Mittler, P. (2012). Working towards inclusive education: Social contexts: New York, NY: Routledge.

Morrison, C. (2015, June). Mediating contemporary learning through spatial change: An account of 'library-as-experimental-space'. Paper presented at the Terrains 2015 Mapping learning environment evaluation across the 
design and education landscape: Towards the evidence-based design of educational facilities, Melbourne. Retrieved from http://e21le.com/wpcontent/uploads/2015/11/Terrains2015WebSmall.pdf

Mulcahy, D., Cleveland, B., \& Aberton, H. (2015). Learning spaces and pedagogic change: Envisioned, enacted and experienced. Pedagogy, Culture \& Society, 23(4), 575-595. doi: 10.1080/14681366.2015.1055128

Organisation for the Economic Co-operation and Development (OECD). (2013). Innovative learning environments. Educational Research and Innovation. Paris: OECD. Retrieved September 30, 2016, from http://www.oecd.org/edu/ceri/innovativelearningenvironments.htm

Organisation for the Economic Co-operation and Development (OECD). (2015). Schools redesigned: Towards innovative learning systems, educational research and innovation. Educational Research and Innovation. Paris: OECD. Retrieved September 20, 2016, from http://www.oecd.org/edu/schooling-redesigned-9789264245914-en.htm

Pearce, M. (2009). The inclusive secondary school teacher in Australia. International Journal of Whole Schooling, 5(2), 1-15. doi: 10.14221/ajte.2009v34n6.7

Pigozzi, G. (2006). What is the quality of education? Educational Review, 58, 14.

Robertson, A. E., \& Simmons, D. R. (2013). The relationship between sensory sensitivity and autistic traits in the general population. Journal of Autism and Developmental Disorders, 43, 775-784. doi: 10.1007/s10803-0121608-7

Robinson, A., \& Munro, L. R. (2014, 16 November). New generation learning environments: Creating good acoustic environments-policy to implementation. Paper presented at the INTER-NOISE and NOISE-CON Congress, Melbourne.

Schrittesser, I., Gerhartz-Reiter, S., \& Paseka, A. (2014). Innovative Learning Environments: About traditional and new patterns of learning. European Educational Research Journal, 13(2), 143-154. doi: 10.2304/eerj.2014.13.2.143

Schunk, D. H., \& Bursuck, W. D. (2012). Self-regulation and disability. In M. Wehmeyer (Ed.), The Oxford handbook of positive psychology and disability. (pp. 265-278.). Oxford, England: Oxford University Press.

Selvaraj, J. (2015). Inclusive education in New Zealand: Policies, politics and contradictions. International Journal of Inclusive Education, 19(1), 86101. doi:10.1080/13603116.2014.907584

Shin, M., Lee, H., \& McKenna, J. W. (2016). Special education and general education preservice teachers' co-teaching experiences: A comparative synthesis of qualitative research. International Journal of Inclusive Education, 20(1), 91-107. doi: 10.1080/13603116.2015.1074732

Solis, M., Vaughn, S., Swanson, E., \& Mcculley, L. (2012). Collaborative models of instruction: The empirical foundations of inclusion and co-teaching. Psychology in the Schools, 49(5), 498-510. doi: 10.1002/pits.21606

Spratt, J., \& Florian, L. (2015). Inclusive pedagogy: From learning to action. Supporting each individual in the context of 'everybody'. Teaching and Teacher Education, 49, 89-96. doi: 10.1016/j.tate.2015.03.006

Thomas, G. (2013). A review of thinking and research about inclusive education policy, with suggestions for a new kind of inclusive thinking. British 
Educational Research Journal, 39(3), 473-490. doi: 10.1080/01411926.2011.652070

United Nations Educational, Scientific and Cultural Organization (UNESCO) (1994). The Salamanca Statement and Framework for Action on Special Needs Education. Paris: UNESCO.

United Nations (2006). Convention on the rights of persons with disabilities.

Retrieved 19 September, 2016, from http://www.un.org/disabilities/convention/conventionfull.shtml

Vaz, S., Wilson, N., Falkmer, M., Sim, A., Scott, M., Cordier, R., \& Falkmer, T. (2015). Factors associated with primary school teachers' attitudes towards the inclusion of students with disabilities. PLOS ONE, 10(8). doi:10.1371/journal.pone.0137002

Waitoller, F. R., \& Artiles, A. J. (2013). A decade of professional development research for inclusive education: A critical review and notes for a research program. Review of Educational Research, 83(3), 319-356.

Walton, E., Nel, N. M., Muller, H., \& Lebeloane, O. (2014). 'You can train us until we are blue in our faces, we are still going to struggle': Teacher professional learning in a full-service school. Education as Change, 18(2), 319-333. doi: 10.1080/16823206.2014.926827

White, S. W., Scahill, L., \& Ollendick, T. H. (2016). Multimodal treatment for anxiety and social skills difficulties in adolescents on the Autism Spectrum. In A. Scarpa, S. White, \& T. Attwood (Eds.), CBT for Children and Adolescents with High-Functioning Autism Spectrum Disorders, (pp. 123-132). New York, NY: Guilford Press. 


\section{ABOUT THE AUTHOR(S)}

\section{ANGELA PAGE \\ University of New England}

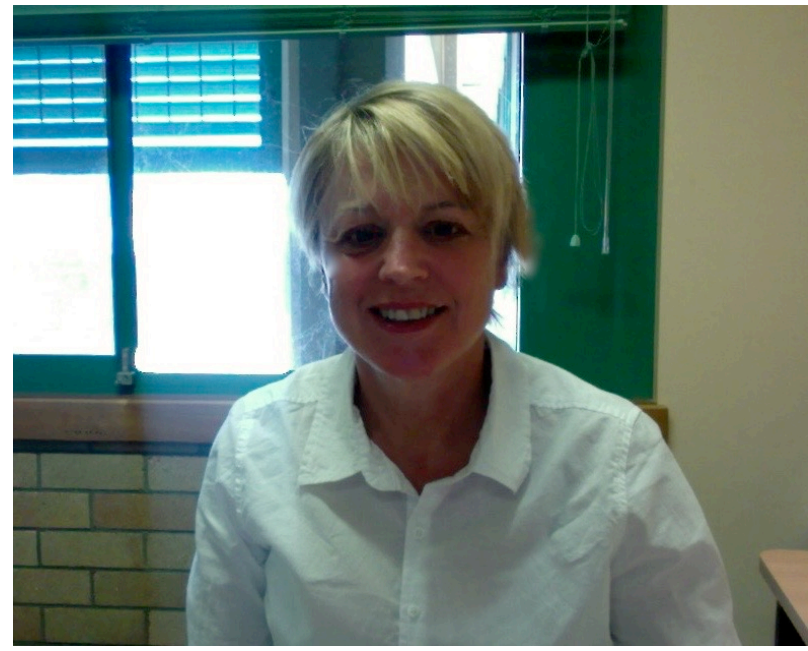

\section{ALEX DAVIS}

\section{Ormiston Senior College}

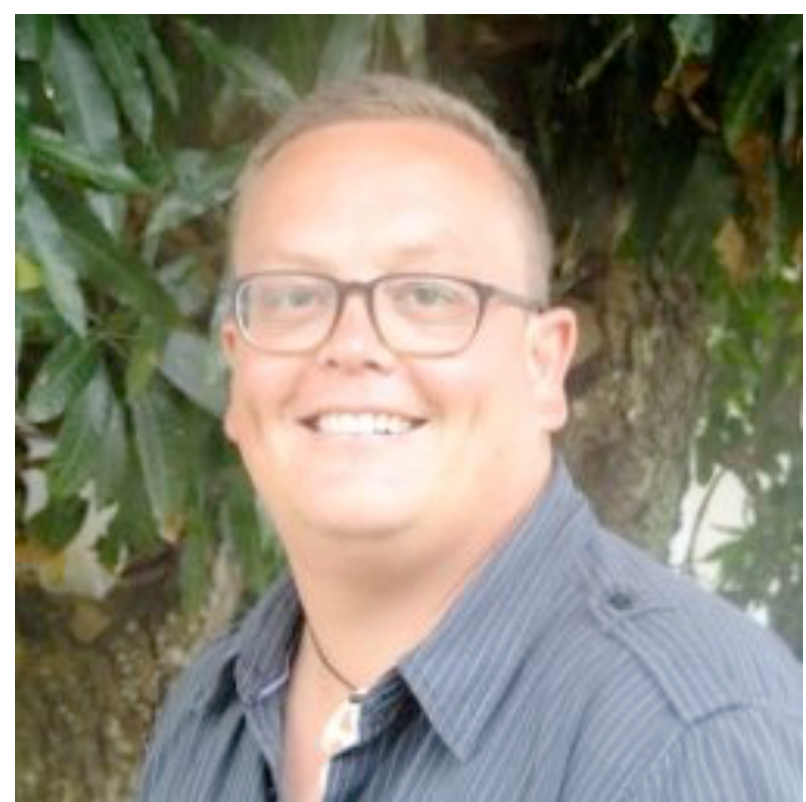

I am originally from New Zealand and worked in the Cook Islands for the last 2 years as an IE and Health and Well-being Advisor to schools. Previously a secondary school teacher, and special education teacher in Nelson, New Zealand, I currently lecture in IE and Psychology at the University of New England in NSW, Australia.
I have recently finished working as a Learning and Teaching Advisor in the Cook Islands where I was able support work around innovative pedagogy and learning spaces. Prior to this, and currently, I am a foundation staff member at Ormiston Senior College in Auckland, New Zealand. Along with my interest in pedagogy and learning in school environments, I am also studying towards a Masters of Indigenous Studies at the University of Auckland

The opinions expressed are those of the paper author(s) and not the New Zealand Journal of Teachers' Work. Copyright is held by individual authors but offprints in the published format only may be distributed freely by individuals provided that the source is fully acknowledged. [ISSN-1176-6662] 